\title{
Synthesis and Spectral Characterization of Schiff Base Cr(III), Mn(III), and Fe(III) Novel Macrocyclic Complexes Derived from Thiocarbohydrazide and Dicarbonyl Compound
}

\author{
GAJENDRA KUMAR $^{\mathrm{a}}$, SHOMA DEVI ${ }^{\mathrm{b}}$, AND RAJEEV JOHARI ${ }^{\mathrm{*}}$ \\ ${ }^{a}$ Chemical Science Laboratory, BIT, Muzaffarnagar 251315, Uttar Pradesh, India \\ ${ }^{b}$ Department of Zoology, Vardhman College, Bijnoar 246701, Uttar Pradesh, India \\ ${ }^{\mathrm{c}}$ Department of Chemistry, Vardhaman College, Bijnor 246701, Uttar Pradesh, India \\ gaj.chem@gmail.com
}

Received 16 November 2011; Accepted 17 January 2012

\begin{abstract}
M(III) Schiff base macrocyclic complexes of the type [HLMX $\left.{ }_{2}\right]$ where $\mathrm{M}=\mathrm{Cr}(\mathrm{III}), \mathrm{Mn}(\mathrm{III}), \mathrm{Fe}(\mathrm{III})$ and $\mathrm{X}=\mathrm{Cl}$, OAc have been synthesized by condensation of acetylacetone and Thio-carbohydrazide $(2: 2)$ in the presence of divalent metal salt in methanolic medium. The complexes have been characterized with the help of elemental analysis, conductance measurements, magnetic measurements and their structural configuration have been determined by various spectroscopic (electronic, IR, ${ }^{1} \mathrm{H} \mathrm{NMR},{ }^{13} \mathrm{C} \mathrm{NMR}$, GCMS) techniques. Electronic and magnetic moments of the complexes indicate that the geometries of the metal centers are octahedral.
\end{abstract}

Keywords: Metal complexes, Spectroscopic study. Thio-carbohydrazide and acetylacetone.

\section{Introduction}

Macrocyclic and compounds have attracted increasing interest owing to their role in the understanding of molecular processes occurring in biochemistry, material science, catalysis ${ }^{1}$. It is well known that $\mathrm{N}$ and $\mathrm{S}$ atoms play a key role in the coordination of metal at the active sides of numerous metallobiomolecules ${ }^{2}$. Metall-organic chemistry is becoming an emerging area of research due to the demand of new metalbased antibacterial and antifingal compounds ${ }^{3,4}$. The aliphatic or aromatic amines can form strong five of six membered chelates rings which are able to produce the metal containing crosslinking agents with required properties ${ }^{5}$. There are a number of important molecules shows biological activities including antibacterial, antifungal ${ }^{6-9}$, antidiabetic ${ }^{10}$, antitumor ${ }^{11}$, antiproliferative ${ }^{12,13}$, anticancer $^{14,15}$, herbicidal ${ }^{16}$, anticorrosion and anti-inflammatory activities ${ }^{6}$ Schiff bases represent an important class of compounds because they are utilized as starting materials in the synthesis of industrial products. Moreover, Schiff bases are regarded as privileged ligands ${ }^{17}$. Due to their capability to form complexes with different transition metals can act as catalysts for many different reactions ${ }^{18,19}$. The discovery and development of effective antibacterial and antifungal drugs with novel mechanism of action have because an urgent 
task for infectious diseases research program ${ }^{20}$. Many investigations have proved that binding of a drug to a netalloelements enhances its activity and in some cases, the complex possesses even more healing properties that the parent $\operatorname{drug}^{21}$. In the present article, we report the synthesis and characterization of Schiff base derived from acetylacetone and thiocarbohydrazide, and its metal complexes to gain more information about related structural and spectral properties as well as their antimicrobial activities.

\section{Experimental}

\section{Reagents}

The entire chemicals used were of the analytical reagent grade, acetylacetone and thiocarbohydrazide procured from Acros and s.d.-fine, respectively. Metal salts were purchased from Merck.

\section{Synthesis of Schiff Base Macrocyclic Ligand}

The macrocyclic Schiff base ligand have been synthesized by refluxing the reaction mixture of acetyl acetone $(2 \mathrm{mmol})$ in ethanol $(30 \mathrm{~mL})$ and Thio-carbohydrazide $(2 \mathrm{mmol})$ in ethanol $(20 \mathrm{~mL})$ for $6-8 \mathrm{~h}$ with addition of $4-5$ drops of concentrate $\mathrm{HCl}$. The reaction mixture was filtered, dried under reduced pressure until a solid product was formed that was washed with cold ethanol and recrystalized from hot ethanol (yield 55-60\%, scheme 1).<smiles>CC(=O)CC(C)=O</smiles>

Scheme 1. Synthesis of Schiff base macrocyclic ligand.

\section{Synthesis of Cr(III), Mn(III), and Fe(III) Macrocyclic Complexes}

A solution of trivalent metal salt $(1 \mathrm{mmol})$ in methanol $(20 \mathrm{~mL})$ was added to a hot solution $\left(75{ }^{\circ} \mathrm{C}\right)$ of macrocyclic ligand in ethanol $(40 \mathrm{~mL})$ and the reaction mixture was refluxed for 10-12h. The complex was precipitated by adding distilled water. The precipitate of the complex was filtered, washed with water, then with hot methanol and finally dried in vacuum desiccator over anhydrous $\mathrm{CaCl}_{2}$ (yield $40-45 \%$, scheme 2). 


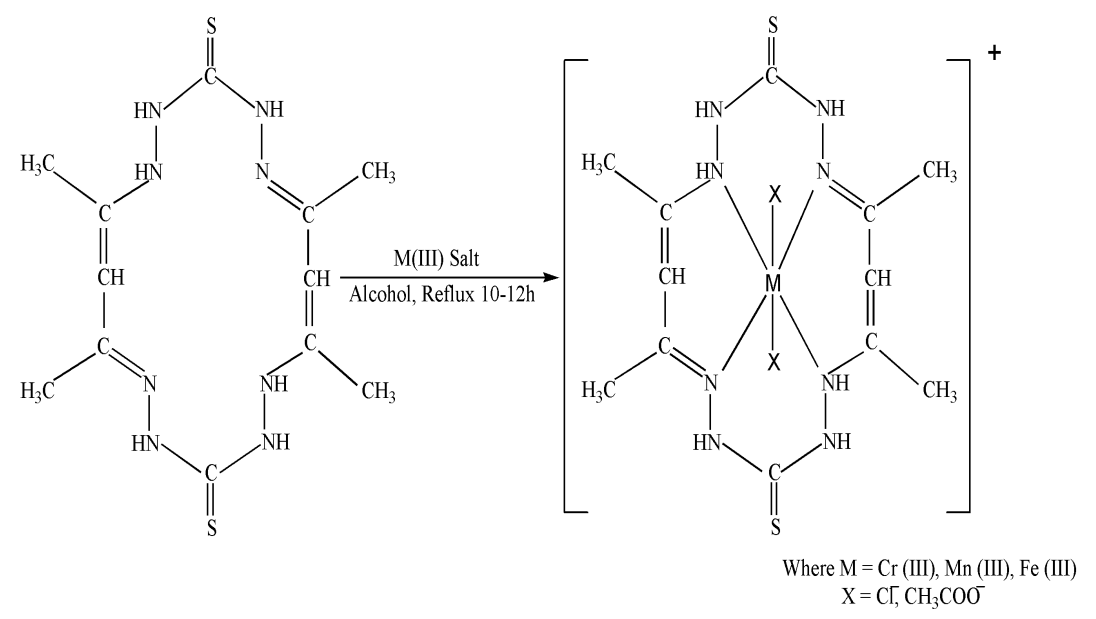

Scheme 2. Synthesis of novel macrocyclic Schiff base complexes.

\section{Analytical and Physical Measurements}

The microanalysis of $\mathrm{C}, \mathrm{H}$, and $\mathrm{N}$ were estimated by elemental analyzer (Perkin Elmer 2400), at SAIF, CDRI, Lucknow, India and the metal contents of Mn (III), Co (III) and Cu (III) was determined using atomic absorption spectrophotometer Perkin Elmer 5000. (See Table I containing also some physical properties of the prepared compounds). The conductivity was measured on digital conductivity meter (HPG system, G-3001) in DMSO at room temperature. The magnetic susceptibility measurements were carried out on Vibrating Sample Magnetometer (Model PAR 155) at room temperature. Electronic spectra (in DMSO) were recorded on a Hitachi 330 spectrophotometer $\left(5815-32573 \mathrm{~cm}^{-1}\right)$. The IR spectra were performed using a FT-IR spectrophotometer Perkin Elmer 1650 in the range $4000-200 \mathrm{~cm}^{-1}$ using Nujol Mull. ${ }^{1} \mathrm{H}$ NMR and ${ }^{13} \mathrm{C}$ NMR spectra (at room temperature) (in DMSO- $\mathrm{d}_{6}$ ) were recorded on a Bruker AVANCE II 300 DRX or average 400 DRX spectrometer with reference to $\mathrm{Me}_{4} \mathrm{Si}(0.0 \mathrm{ppm})$. The $\mathrm{FAB}$ mass spectra (at room temperature) were recorded on VG-70-S mass spectrometer. The purity of the Schiff base and its complexes were confirmed also by TLC [microcrystalline cellulose (E. Merck) was used for the preparation of thin layer, complete separation was achieved with the solvent system acetone/conc. $\mathrm{HCl} /$ water $(86: 8: 7)$. $\mathrm{R}_{\mathrm{F}}$ values increase in the following order of $\mathrm{M}$ (III) complexes: $\mathrm{Cr}, \mathrm{Mn}, \mathrm{Fe}(0.28,0.42,0.61)]$ and HPLC. The HPLC chromatographic apparatus consisted of a model waters 600 pump with waters 600 controller, waters 2996 photodiode array detector with UV detection $254 \mathrm{~nm}$, flow rate $1 \mathrm{ml} / \mathrm{min}$ a discovery $\mathrm{C}_{8}, 15 \mathrm{~cm} \mathrm{X} 4.6 \mathrm{~mm}$ I.D, $5 \mu \mathrm{m}$ particles and mobile phase methanol:25 mm KH${ }_{2} \mathrm{PO}_{4}(20: 80) \mathrm{PH}=3$ techniques.

\section{Results and Discussion}

\section{Mass Spectra}

The FAB mass Spectra of Cr(III), Mn(III) and Fe(III) Schiff base complexes have been recorded. The molecular ion $\left(\mathrm{M}^{+}\right)$peaks obtained from various complexes are as follows: (1) $\mathrm{m} / \mathrm{e}=340.48$ (Ligand), (2) $\mathrm{m} / \mathrm{e}=474.93($ complex 1), (3) $\mathrm{m} / \mathrm{e}=522.12($ complex 2), (4) $\mathrm{m} / \mathrm{e}$ $=470.08$ (complex 3), (5) $\mathrm{m} / \mathrm{e}=517.27$ (complex 4), (6) $\mathrm{m} / \mathrm{e}=470.32($ complex 5$),(7) \mathrm{m} / \mathrm{e}$ $=517.51$ (complex 6$)$. This data is in good agreement with the proposed molecular formula for these complexes. In addition to the peaks due to the molecular ion, the spectra exhibit 
peaks assignable to various fragments arising from the thermal cleavage of the complexes. The peak intensity gives an idea of the stability of the fragments.

\section{Infrared Spectra}

The IR spectra provide valuable information regarding the nature of functional group attached to the metal atom. The presence of a single medium band in the region 3250-3330 $\mathrm{cm}^{-1}$ in the complexes may be assigned to $\mathrm{N}-\mathrm{H} \mathrm{stretch}^{22}$. It was noted that a pair of bands corresponding to ${ }_{\mathrm{v}}\left(\mathrm{NH}_{2}\right)$ at $3245 \mathrm{~cm}^{-1}$ and $3309 \mathrm{~cm}^{-1}$ are present in the spectra of the thiocarbohydrazide. The value of ${ }_{V}(C=N)$ stretching vibration is found lower $(1520-1560$ $\left.\mathrm{cm}^{-1}\right)$ than the expected value $\left(1580-1650 \mathrm{~cm}^{-1}\right)$. This lower value of ${ }_{v}(\mathrm{C}=\mathrm{N})$ stretching may be explained on the basis of a drift of lone pair density of azomethine nitrogen towards the metal atom ${ }^{23}$ indicating that coordination takes place through nitrogen of $(\mathrm{C}=\mathrm{N})$ groups. The bands present in the range $3020-3040 \mathrm{~cm}^{-1}$ may be assigned due to $(\mathrm{C}-\mathrm{H})$ stretching vibrations of benzil and naphthalene ring ${ }^{24}$. The $\mathrm{C}-\mathrm{N}$ stretch in the range $1000-1300 \mathrm{~cm}^{-}{ }^{1}$. The band near $780 \mathrm{~cm}^{-1}$ in thiocarbohydrazide may be assigned as being due to free ${ }_{\mathrm{v}}(\mathrm{C}=\mathrm{S})$. The band at 3292-3438 $\mathrm{cm}^{-1}$ is due to the presence of OH group in the complexes. This band is also present in the spectra of all the complexes, which indicate that sulphur is not coordinating to the metal atom ${ }^{25}$. The far infrared spectra show bands in the region 420-450 $\mathrm{cm}^{-1}$ corresponding to ${ }_{\mathrm{v}}(\mathrm{M}-\mathrm{N})$ vibrations ${ }^{26}$. The presence of bands in all complexes in the region $420-450 \mathrm{~cm}^{-1}$ originates from the $(\mathrm{M}-\mathrm{N})$ azomethine vibrational modes and identifies coordination of azomethine nitrogen ${ }^{27}$. The bands present at $290-310 \mathrm{~cm}^{-1}$ may be assigned due to ${ }_{\mathrm{v}}(\mathrm{M}-\mathrm{Cl})$ vibrations $^{28}$.

The appearance of two characteristic bands in the ranges $1561-1559 \mathrm{~cm}^{-1}$ and $1370-1367$ $\mathrm{cm}^{-1}$ in the case of complexes was attributed to $v_{\text {asym }}\left(\mathrm{COO}^{-}\right)$and $v_{\text {sym }}\left(\mathrm{COO}^{-}\right)$, respectively, indicating the participation of the carboxylate oxygen in the complexes formation. The mode of coordination of carboxylate group has often been deduced from the magnitude of the observed separation between the $v_{\text {asym }}\left(\mathrm{COO}^{-}\right)$and $v_{\text {sym }}\left(\mathrm{COO}^{-}\right)$. The separation value, $\Delta v\left(\mathrm{COO}^{-}\right)$, between $v_{\text {asym }}\left(\mathrm{COO}^{-}\right)$and $v_{\text {sym }}\left(\mathrm{COO}^{-}\right)$, in these complexes were more than 190 $\mathrm{cm}^{-1}\left(191-193 \mathrm{~cm}^{-1}\right)^{29}$.

\section{${ }^{1} H N M R$}

A survey of literature reveals that the NMR spectroscopy has been proved useful in establishing the structure and nature of many Schiff base ligand and their complexes. The ${ }^{1} \mathrm{H}$ NMR spectra of Schiff base ligand (HL) was recorded in $\mathrm{d}_{6}$-dimethylsulfoxide (DMFO- $\mathrm{d}_{6}$ ) solution using $\mathrm{Me}_{4} \mathrm{Si}$ (TMS) as internal standard. The ${ }^{1} \mathrm{H}$ NMR spectra of the ligand shows broad signal at 9.4-12.1 ppm due to the $-\mathrm{NH}$ [30]. The multiplets in the region 1.12-1.56 ppm may be assigned to aliphatic proton $^{30}$.

${ }^{13} \mathrm{C}$ NMR of the Schiff base ligand, the signal appeared in the region 113-158 are assigned to aromatic carbon. The signal at 198.3-185.6, 182.8-171.2, 165.4-150.7 and 148.1- 15.8 ppm are due to $\mathrm{C}=\mathrm{S}, \mathrm{C}=\mathrm{N}, \mathrm{C}=\mathrm{O}$ and $\mathrm{CH}_{3}$ respectively.

\section{Magnetic Measurements and Electronic Spectral Studies}

The electronic spectra of $\mathrm{Cr}$ (III) complexes 1 and 2 showed absorption band in the region 8950-9310, 13150-13520, 17550-18450 and 27380-27780 $\mathrm{cm}^{-1}$ attributed to ${ }^{4} \mathrm{~B}_{1 \mathrm{~g}} \rightarrow{ }^{4} \mathrm{E}_{1 \mathrm{~g}}$, ${ }^{4} \mathrm{~B}_{1 \mathrm{~g}} \rightarrow{ }^{4} \mathrm{~B}_{2 \mathrm{~g}},{ }^{4} \mathrm{~B}_{1 \mathrm{~g}} \rightarrow{ }^{4} \mathrm{~A}_{2 \mathrm{~g}}$ and ${ }^{4} \mathrm{~B}_{1 \mathrm{~g}} \rightarrow{ }^{4} \mathrm{E}_{\mathrm{g}}$ transition indication of octahedral geometry ${ }^{31}$. The magnetic moment value for this complex was found to be 4.38-4.68 B.M.

The absorption spectral bands of manganese (III) complexes 3,4 showed three spin allowed transitions: ${ }^{5} \mathrm{~B}_{1 \mathrm{~g}} \rightarrow{ }^{5} \mathrm{~A}_{1 \mathrm{~g}},{ }^{5} \mathrm{~B}_{1 \mathrm{~g}} \rightarrow{ }^{5} \mathrm{~B}_{2 \mathrm{~g}},{ }^{5} \mathrm{~B}_{1 \mathrm{~g}} \rightarrow{ }^{5} \mathrm{E}_{\mathrm{g}}$ appearing in the ranges $12250-12550,16150$ 18860 , and $35450-35720 \mathrm{~cm}^{-1}$, respectively consistent with a typical $\mathrm{Mn}(\mathrm{III})$ in an octahedral environment ${ }^{32}$. The magnetic moment values for these complexes were found in the range 4.92-5.14 B.M expected for octahedral nickel complexes. 
The electronic spectra of the iron (III) complexes (5) and (6) gave two bands at 9850-9980, and 27650-27760 $\mathrm{cm}^{-1}$, which could be assigned to the transitions ${ }^{6} \mathrm{~A}_{1 \mathrm{~g}} \rightarrow{ }^{4} \mathrm{~T}_{1 \mathrm{~g}}$ and ${ }^{6} \mathrm{~A}_{1 \mathrm{~g}} \rightarrow{ }^{4} \mathrm{~T}_{2 \mathrm{~g}}$, respectively, suggesting an octahedral geometry around $\mathrm{Fe}$ (III) ion ${ }^{33}$. The complexes 5 and 6 show magnetic moment values in the range 5.38-5.45 B.M., which is smaller than the calculated value for two Fe (III) ions in octahedral geometries and this may be due to antiferromagnetism between the two ion-centers.

The spectral characterization show the formula for macrocyclic complexes as $\left[\mathrm{M}\left(\mathrm{C}_{12} \mathrm{H}_{20} \mathrm{~N}_{8} \mathrm{~S}_{2}\right) \mathrm{X}_{2}\right] \mathrm{X}$ where $\mathrm{M}=\mathrm{Cr}(\mathrm{III}), \mathrm{Mn}(\mathrm{III}), \mathrm{Fe}(\mathrm{III})$, and $\mathrm{X}=\mathrm{Cl}^{-}, \mathrm{CH} 3 \mathrm{COO}^{-}$. The measurements of molar conductance in DMSO are 21-66 $\mathrm{Scm}^{2} \mathrm{~mol}^{-1}$. All complexes give satisfactory elemental analyses data as shown in table 1 . On the bases of various studies like elemental analysis, conductance measurements, magnetic susceptibilities, IR, NMR, electronic and mass spectral studies the geometry of the complexes are octahedral.

Table 1. Elemental analysis in $\%$ and molar conductance $\left(\Lambda_{\mathrm{M}}\right.$ in DMSO) in $\mathrm{Scm}^{2} \mathrm{~mol}^{-1}$ and magnetic moment $\left(\mu_{\mathrm{eff}}\right)$ in $\mu_{\mathrm{B}}$ of the Schiff base ligand and its metal complexes.

\begin{tabular}{|c|c|c|c|c|c|c|c|c|}
\hline Complex & FW & Colour & $\begin{array}{l}\mathrm{C} \\
\text { Calc. } \\
\text { (Found) }\end{array}$ & $\begin{array}{l}\mathrm{H} \\
\text { Calc. } \\
\text { (Found) }\end{array}$ & $\begin{array}{l}\mathrm{N} \\
\text { Calc. } \\
\text { (Found) }\end{array}$ & $\begin{array}{l}\text { M } \\
\text { Calc. } \\
\text { (Found) }\end{array}$ & $\Lambda_{\mathrm{M}}$ & $\mu_{\text {eff }}$ \\
\hline $\mathrm{C}_{12} \mathrm{H}_{20} \mathrm{~N}_{8} \mathrm{~S}_{2}$ & 340.48 & yellow & $\begin{array}{l}42.33 \\
(42.28)\end{array}$ & $\begin{array}{l}5.92 \\
(5.91)\end{array}$ & $\begin{array}{l}32.91 \\
(32.85)\end{array}$ & & & \\
\hline $\begin{array}{l}{\left[\mathrm{Cr}\left(\mathrm{C}_{12} \mathrm{H}_{20} \mathrm{~N}_{8} \mathrm{~S}_{2}\right)\right.} \\
\left.\mathrm{Cl}_{2}\right] \mathrm{Cl}\end{array}$ & 498.83 & Orange & $\begin{array}{l}28.89 \\
(28.81)\end{array}$ & $\begin{array}{l}4.04 \\
(4.12)\end{array}$ & $\begin{array}{l}22.47 \\
(22.48)\end{array}$ & $\begin{array}{l}10.42 \\
10.40\end{array}$ & 59 & 4.38 \\
\hline $\begin{array}{l}{\left[\mathrm{Cr}\left(\mathrm{C}_{12} \mathrm{H}_{20} \mathrm{~N}_{8} \mathrm{~S}_{2}\right)\right.} \\
\left.\mathrm{OAc}_{2}\right] \mathrm{OAc}\end{array}$ & 569.61 & $\begin{array}{l}\text { Greenish } \\
\text { Yellow }\end{array}$ & $\begin{array}{l}37.96 \\
(37.95)\end{array}$ & $\begin{array}{l}5.13 \\
(5.14)\end{array}$ & $\begin{array}{l}19.67 \\
(19.72)\end{array}$ & $\begin{array}{l}9.13 \\
(9.15) \\
\end{array}$ & 66 & 4.68 \\
\hline $\begin{array}{l}{\left[\mathrm{Mn}\left(\mathrm{C}_{12} \mathrm{H}_{20} \mathrm{~N}_{8} \mathrm{~S}_{2}\right)\right.} \\
\left.\mathrm{Cl}_{2}\right] \mathrm{Cl}\end{array}$ & 501.78 & Brown & $\begin{array}{l}28.72 \\
(28.70)\end{array}$ & $\begin{array}{l}4.02 \\
(4.00)\end{array}$ & $\begin{array}{l}22.33 \\
(22.35)\end{array}$ & $\begin{array}{l}10.95 \\
(10.91)\end{array}$ & 21 & 4.92 \\
\hline $\begin{array}{l}{\left[\mathrm{Fe}\left(\mathrm{C}_{12} \mathrm{H}_{20} \mathrm{~N}_{8} \mathrm{~S}_{2}\right)\right.} \\
\left.\mathrm{OAc}_{2}\right] \mathrm{OAc}\end{array}$ & 572.56 & Gray & $\begin{array}{l}37.76 \\
(37.75)\end{array}$ & $\begin{array}{l}5.11 \\
(5.05)\end{array}$ & $\begin{array}{l}19.57 \\
(19.55)\end{array}$ & $\begin{array}{l}9.60 \\
(9.55)\end{array}$ & 28 & 5.14 \\
\hline $\begin{array}{l}{\left[\mathrm{Fe}\left(\mathrm{C}_{12} \mathrm{H}_{20} \mathrm{~N}_{8} \mathrm{~S}_{2}\right)\right.} \\
\left.\mathrm{Cl}_{2}\right] \mathrm{Cl}\end{array}$ & 502.68 & $\begin{array}{l}\text { Light } \\
\text { Yellow }\end{array}$ & $\begin{array}{l}28.67 \\
(28.65)\end{array}$ & $\begin{array}{l}4.01 \\
(3.98)\end{array}$ & $\begin{array}{l}22.29 \\
(22.32)\end{array}$ & $\begin{array}{l}11.11 \\
(11.12)\end{array}$ & 29 & 5.38 \\
\hline $\begin{array}{l}{\left[\mathrm{Fe}\left(\mathrm{C}_{12} \mathrm{H}_{20} \mathrm{~N}_{8} \mathrm{~S}_{2}\right)\right.} \\
\left.\mathrm{OAc}_{2}\right] \mathrm{OAc}\end{array}$ & 573.46 & Reddish & $\begin{array}{l}37.84 \\
(37.85)\end{array}$ & $\begin{array}{l}5.10 \\
5.05\end{array}$ & $\begin{array}{l}19.54 \\
(19.51)\end{array}$ & $\begin{array}{l}9.74 \\
(9.70)\end{array}$ & 38 & 5.45 \\
\hline
\end{tabular}

\section{Conclusion}

The analytical data show the presence of one metal ion per ligand molecule and suggest a mononuclear structure for the complexes. The electronic spectral data is in the favor of octahedral geometry of the complexes.

\section{Acknowledgment}

The authors express their sincere thank to the head Department of Applied Science, Director and Management BIT. Muzaffarnagar, (UP) India for their encouragement and providing research facilities and to CDRI Lucknow and IIT Roorkee for providing mass, electronic and IR spectral data. 


\section{References}

1. Busch, D.H., Science, 1971, 171, 241.

2. Bagihalli, G.B., Avaji, P.G., Patil, S.A., Badami, P.S., Eur. J. Med. Chem. 2008, 43, 2639.

3. Scozzafava, A., Supuran, C.T., J. Med. Chem. 2000, 43, 3677.

4. Rice, S.A., Givskov, M., Steinberg, P., Kjelleberg, S., J. Mol. Microbiol. Biotechnol. 1999, 1, 23.

5. Kurnoskin, A.V., Polym. Compos. 1993, 14, 481.

6. Kumar, G., kumar, D., Singh, C.P., Kumar, A., Rana, V.B., J. Serb. Chem. Soc. 2010, 75, 629.

7. Singh, D.P., Kumar, K., Sharma, C., Eur. J. Med. Chem. 2009, 44. 3299.

8. Singh, K., Bharwa, M.S., Tyagi, P., Eur. J. Med. Chem. 2007, 42, 394.

9. Kumar, G., kumar, D., Devi, S., Johari, R., Singh, C.P., Eur. J. Med. Chem. 2010, 45, 3056.

10. Vanco, J., Marek, J., Travnicek, Z., Racanska, E., Muselik, J., Svajlenova, O., J. Inorg. Biochem. 2008, 102, 595.

11. Galal, S.A., Hegab, K.H., Kassab, A.S., Rodriguez, M.L., Kervin, S.M., El-Khamry, A.M.A., El-Diwani, H.I., Eur. J. Med. Chem. 2009, 44, 1500.

12. Chaviara, A.T., Cox, P.J., Repana, K.H., Papi, R.M., Papazisis, K.T., Zambouli, D., Kortsaris, A.H., Kyriakidis, D.A., Bolos, C.A., J. Inorg. Biochem. 2004, 98, 1271.

13. Illan-Cabeza, N.A., Hueso-Urena, F., Moreno-Carretero, M.N., Martinez-Martos, J.M., Ramirez-Exposito, M.J., J. Inorg. Biochem. 2008, 102, 647.

14. Desai, S.B., Desai, P.B., Desai, K.R., Heterocycl. Commun. 2001, 7, 83.

15. Pathak, P., Jolly, V.S., Sharma, K.P., Orient. J. Chem. 2000, 16, 161.

16. Samadhiya, S., Halve, A., Orient. J. Chem. 2001, 17, 119.

17. Yoon, T.P., Jacobsen, E.N., Science, 2003, 299, 1691.

18. Mirkhani, V., Moghadam, M., Tangestaninejad, S., Mohammadpoor-Baltork, I., Rasouli, N., Catal. Commun. 2008, 9, 219.

19. Chen Y., Ruppel, J.V., Zhang X.P., J. Am. Chem. Soc. 2007, 129, 12074.

20. Smith, H.J., Simons C., Proteinase and Peptidase Inhibition: Recent Potential Targets for Drug Development, Taylor and Francis, London, 2001.

21. Lippard, S.J., Berg, J.M., Principles of Bioinorganic Chemistry, University Science Books, Mill Valley, CA, 1999.

22. Bain, G.A., West, D.X., Krejci, J., Martinez, J.V., Ortega, S.H., Toscano, R.A., Polyhedron. 1997, 16, 855.

23. Lodeiro, C., Basitida, R., Bertolo, E., Macias, A., Rodriguez, R., Transition Met. Chem. 2003, 28, 388.

24. Mikhailov, O.V., Kazymova, M.R., Shumilova, T.A., Solovieva, S.S., Transition Met. Chem. 2004, 20, 732.

25. Chandra, S., Thakur, S., Transition Met. Chem. 2004, 29, 925.

26. Shakir, M., Islam, K.S., Mohamed, A.K., Shagufa M., Hasan, S.S., Transition Met. Chem. 1999, 24, 577.

27. Rana, V.B., Singh, D.P., Singh, P., Teotia, M.P., Transition Met. Chem. 1982, 7, 174

28. Khan, T.A., Hasan, S.S., Varkey, S.P., Rather, M.A., Jahan, N., Shakir, M., Transition Met. Chem. 1997, 22, 4.

29. Boghaei, D.M., Gharagozlou, M., Spectrochem. Acta, 2007 67A, 944.

30. Gunthkal, M.S., Goudal, T.R., Patil, S.A., Oriental J. Chem. 2000, 16, 151.

31. Wood, J.S., Prog. Inorg. Chem. 1971, 16, 227.

32. Singh, D.P., Rana, V.B., Polyhedron, 1995, 14, 2901.

33. A.B.P. Lever, Inorganic Electronic Spectroscopy, Elsevier, Amsterdam, 1984. 


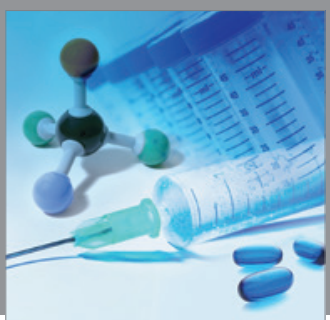

International Journal of

Medicinal Chemistry

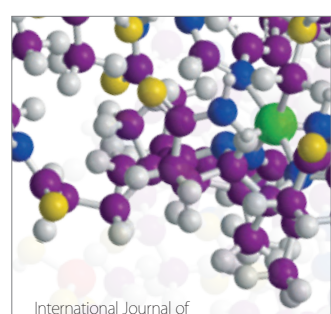

Carbohydrate Chemistry

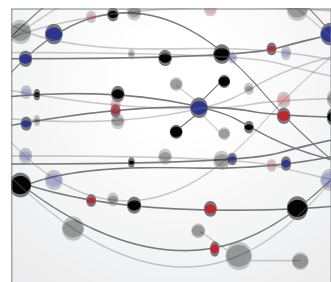

The Scientific World Journal
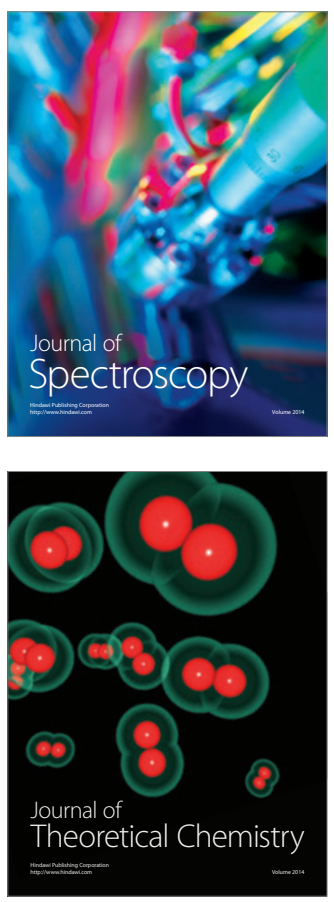
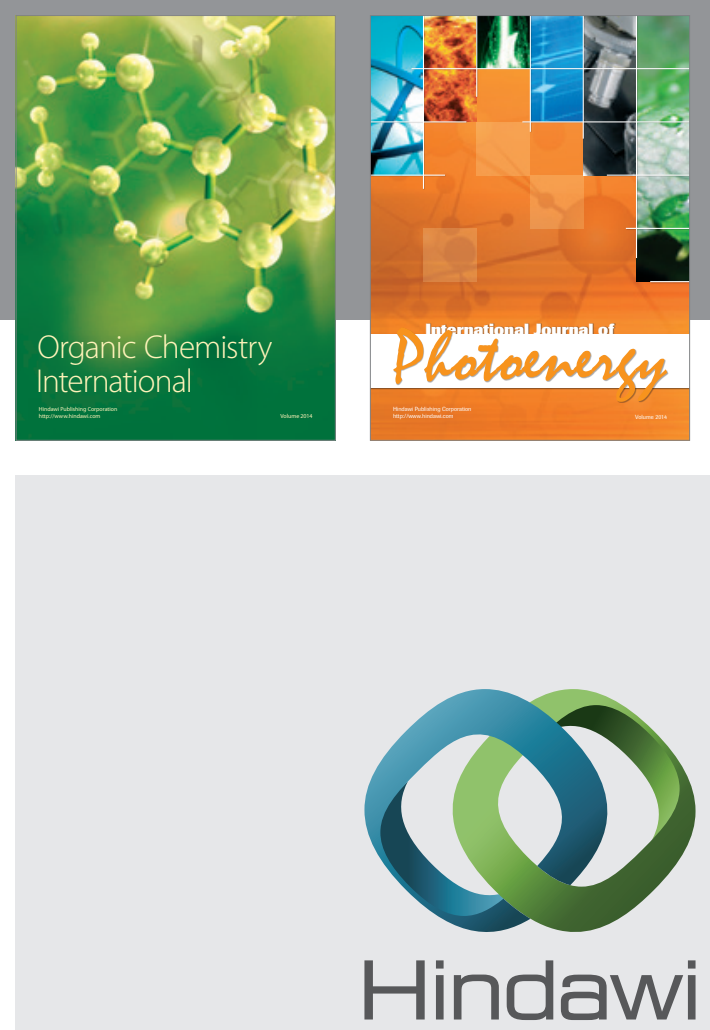

Submit your manuscripts at

http://www.hindawi.com
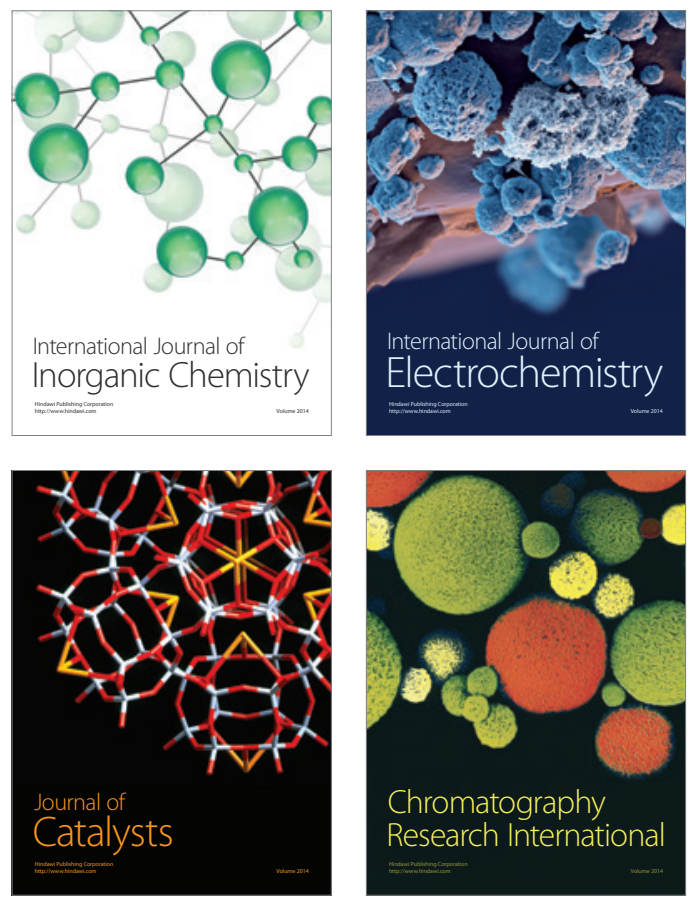
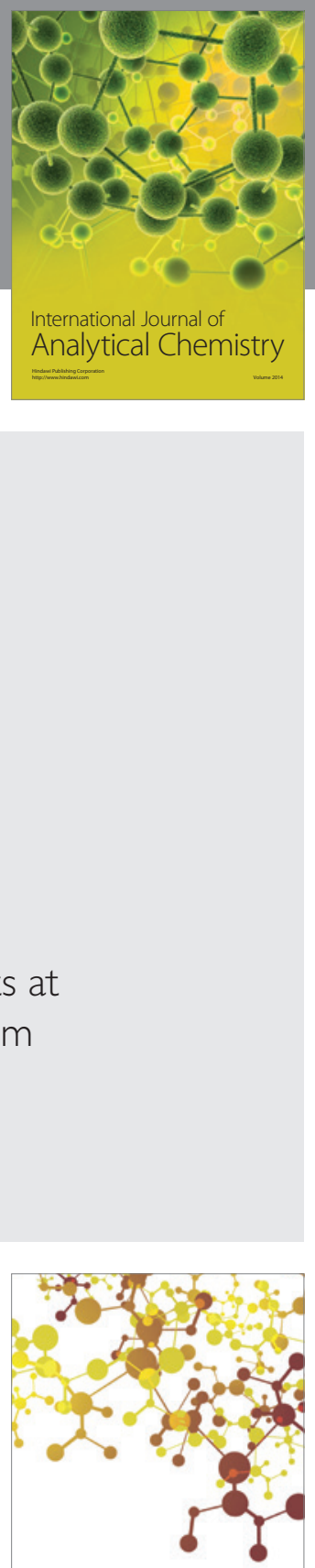

Journal of

Applied Chemistry
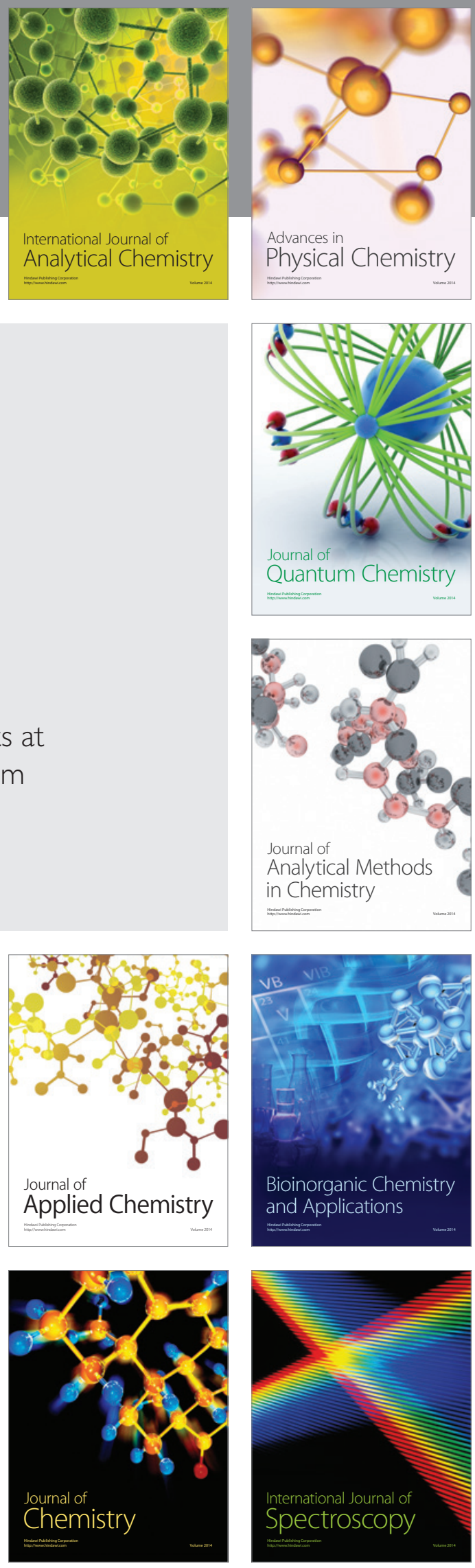